\title{
Influence of Parental Marital Status, Family Type and Size on Academic Performance of Secondary School Students in Agricultural Science in Adamawa State Nigeria
}

\author{
Egunsola, A. O. E. (PhD) \\ Department of Vocational Education School of Technology and Science Education Modibbo Adama University \\ of Technology, Yola Adamawa State Nigeria
}

\begin{abstract}
This study used ex-post facto and correlation survey to investigate the influence of marital status, family size and type on academic performance of senior secondary students in Adamawa State. The population of the study consisted of 8,548 students in class 2 in 2012/13 to 2013/14 academic sessions. A total sample of 900 students was drawn from the population using multi-stage random sampling technique to respond to the instrument for data collection for the study. The instrument was a 40 items researcher designed questionnaire titled Home Environment Factors and Students' Academic Achievement Test in Agricultural Science (HEFSAATAS) consisting of two sections A and B. Inferential statistics z-test and correlation analysis were used to describe, analyse and interpret the data. The results showed that parental marital status $(r=0.79)$ and family size $(r=0.81)$ were highly correlated with students' academic performance while family type $(z=3.48$, significant at $P<0.05,1.96)$, family size and parental marital status have significant influence on students' performances in Agricultural Science at the secondary school. It was recommended that parents should maintain intact marriage and family institutions for good parenting; and keep family sizes and types they can sponsor, run and maintain.
\end{abstract}

Key Words: Marital Status, Family Type, Family Size, Academic performance,

\section{Introduction}

Over a period of time, it has been observed that students exposed to the same lessons by the same teachers perform differently when they are evaluated. This shows that outside the school environment, other factors influence students' academic performance. Also differences in the academic performances of gifted and non gifted children cannot be traced to school environment. Hence, many other uncontrolled variables can be responsible for academic performance of students generally, secondary school students inclusive. Adesehinwa (2013) reported effect of family type and poor funding on students' academic achievement; Ogbemudia and Aiasa (2013) reported lack of good home foundation for pupils as cause of poor performance by students; Achieng (2012) found home factors, student factors and institutional capacity as the causes while Adesehinwa and Aremu (2010) posited that factors resident in child, family, society, government and the school may be composite causative effects for these downtrend; they, however concluded that there is a need for each of these variables to be considered extensively, hence the focus of this study to critically consider influence of home on academic performance of secondary school students.

Other studies showed that the level of family cohesion (Caplan et al, 2002 as cited by Diaz, 2004), and family relationships (Buote, 2001) proved themselves capable of predicting performance. Schiefelbaum and Simmons (2000) cited in Adell (2002) consider family background the most important and most weighty factor in determining the academic performance attained by the student. Among family factors of greatest influence are social class variables and the educational and family environment. Emeke (1984) stressed that the environmental condition and the nature of social interaction that goes on in the family may have some positive or negative influence on the academic achievement of a child. One of the tasks of Education is to train young people to become useful members of the society and this training begins at home in the informal way. The home of the child is the first place he/she enters when born into the world by parents.

A home is a place where pupils live with their parents or guardian and it is the place where they are groomed. It is a place where the pupils begin to learn the norms and values of the society in which they find themselves. The family is a social unit in any society and it is the source of early stimulation and experience in children (Collins, 2007). The home influences the child at the most earliest possible time of his life at a time when his mind is most receptive. It provides the first impression which may last through the whole life of the child. The child often sees the parents, siblings and things in their immediate environment to be most significant and they are capable of promoting or diminishing him in self worth and academic performance (Ekanem, 2004). 
The family, being a powerful influence on the child and its importance as a primary agent of socialization could in no doubt enhance or hinder the academic achievement of the child depending on the social climate in the family. Variance in psycho-social emotional fortification in the family background could be an indicator to high or low academic performance of students, bearing in mind the intervening effect of high and low socio-economic status and emotional stability of students which is a pre-requisite to academic achievement (Adebule, 2004). This is because psychological problems are potential sources of trouble with learning. It is therefore against these backgrounds that this study sought to determine influence of home environment on academic performance of secondary school students in Adamawa State.

The environment is the immediate surrounding in which the pupils find themselves. It is also referred to as the physical and psychological conditions that affect children (Ogbemudia \& Aiasa, 2013). The parents or guardian of the students are responsible for providing the right home environment that will facilitate effective learning for their wards. Furthermore, in pupil's home environment, some factors that influences their academic performances include: parental educational background, occupation, economic status, marital status and home location; family size and peer group.

The home environment means the family background of the students; this includes all the human and material resources present at the home that affects the student's education and living, such as the parent's level of education, their occupation, socio-economic status and socializing facilities available in the house, number of siblings and even family type. Thus, the home is the basic institution for providing the child's primary socialization and laying the educational foundation for the child upon which the other agents of socialization are built.

The education received by a child from parents and significant others at home is most likely to have a highly significant and dominant effects on the behaviours of the child later in life. What the child learns at home and how his/her family motivates him/her towards education contributes to the child's success or failure at school. Even though, environment also plays a very remarkable role in the life and educational success of every individual.

As a result of the need to train the young people, the Federal Government of Nigeria in 1976 produced a document - National Policy on Education (NPE) to guide and help the home and schools in their bid to achieve this great task. The NPE contains the national objectives for education, secondary school education in particular should:

a. Provide all primary school graduates with the opportunity to further their education at a higher level irrespective of sex, religion or ethnic background

b. Cater for differences in interests, talents for opportunity and future roles

c. Preserve cultural heritage by developing and promoting the Nigerian languages, arts and culture

d. Foster national unity by emphasizing the divers common ties that unite Nigerians

e. Raise a generation of people who can think for themselves, respects the views and feelings of others, respects the dignity of labour, be a patriotic and good citizens.

Agricultural science teaching and learning (farming) has a long history of being Nigeria's cultural heritage passed on from one generation to the next by the fore fathers as a necessary vocation to maintain the food and fibre chains which were the main means of survival. Nowadays, farming business is no more interesting and attractive to the youths; youngsters who should be the future farmers do not value farming vocations despite all its multifarious benefits. Thus, many young people do not like going in to agricultural education because many regard agricultural studies and its allied vocations as a job and business for the less intelligent or poor academic achievers. But this is far from the reality! This is one of the reasons for dwindling students' enrolment in the Agricultural Science discipline and its associated fields of studies (Egunsola, 2012); thus, attracting quality students to choose agricultural science subject remains one of the most vital duty of agricultural science educators.

Campbell and Martin (2003) reported that agricultural education has a long history in education (Nigeria inclusive), based on the beliefs of students enrolled in the program, agricultural education remains one of the most widely praised secondary school programs. Most programs consist of classroom and laboratory instruction, agricultural clubs. Students and teachers spend time in and outside the school following the curriculum and working on projects. Farm businesses dominated rural life and sustained rural communities. Technological evolution has transformed the nature and vastly broadened the range of agricultural occupations and professional careers. Thus, many industries now serve agriculture by producing, processing, marketing, and preparing food and fibre products for consumers (Campbell and Martin, 2003).

Agriculture broadly defined, is too vital a topic to be taught only to the relatively small percentage of students considering careers in agriculture and pursuing studies in agriculture. Students should come to appreciate that the plants and animals providing our food and fibre are part of a vast web of life that functions as an integrated whole. Every species of plant and animal depends not only on its physical environment, but on the biological component of the environment as well. All living creatures are part of the same cycles of matter and 
energy. Education will be incomplete unless students are exposed to learn what is essential for the lives of our crops, animals and plants (Myers et al., 2004).

The purpose of this study was to determine the influence of home environment on academic performance of students in Agricultural Science in Adamawa State secondary schools. Specifically, the study will:

a. determine the influence of marital status of parents on students performance

b. determine the influence of family type on the academic performance of students

c. determine the influence of family size on the academic performance of students

The following hypotheses were postulated for the study:

1. Parental marital status will not have significant influence on students' academic performance in Agricultural Science at the secondary school

2. Family type (monogamy or polygamy) of parents will not have significant influence on students' academic performance in Agricultural Science at the school

3. Family size in home of students will not have significant influence on academic performance of students in Agricultural Science at the secondary school

All the postulated hypotheses were tested at 0.05 levels of significance.

\section{Theoretical and Empirical Framework}

This study was based on Cause and Effect Theory. Cause and effect describes how something happens, analyses why something happens; examines cause, describes effect or do both because it links situations and events together in time, with cause preceding effect (Epp, 2004). Furthermore, causality refers to cause-andeffect analysis, it explains why something happened, or is happening and it predicts what probably will happen. Sometimes, many different causes may be responsible for one effect, and similarly, many different effects could be produced by a single cause. In logic, causes are often distinguished in to two types: necessary and sufficient. If $x$ is a necessary cause of $y$, then the presence of $y$ necessarily implies the presence of $x$. The presence of $x$, however, does not imply that $\mathrm{y}$ will occur. If $\mathrm{x}$ is a sufficient cause of $\mathrm{y}$, then the presence of $\mathrm{x}$ necessarily implies the presence of $y$. However, another cause $z$ may alternatively cause $y$, thus the presence of $y$ does not imply the presence of $x$ (Epp, 2004). Cause and effect is established through intervention trial in which two or more groups undergo the same experience except for a single facet. The single facet in this study is home environment. Any difference in outcome is then attributed to that single facet (Freedman, 1999). Causality (causation) denotes a logical relationship between one event (called cause) and another event (called effect) which is the direct consequence of the first. The cause in this study is home environment while academic performance of student is the effect.

In this study, the researcher focused on assessing parental marital status on pupil's academic performance, the home environment that is tensed due to divorce or unhealthy atmosphere of quarrelling; fighting due to large family size and polygamy cannot favour learning, as the mind of the pupils will not be settled in order to give room for creativity. Ogbemudia and Aiasa (2013) maintained that physical and psychological conditions of the home environment affect the children academically. Ekanem (2004) stated that harmonious home create emotional stability in the child at home and subsequently throughout his school life. Hence the researcher was also concerned with the careful study of the influence of single parenthood due to broken home, death, widowhood and intact home on the academic performance of students.

The parenting style (democratic, authoritarian, etc) is also influential both in the students' educational process as well as in family-school relations; research such as that by Rodriguez (1986) demonstrated that a positive family climate favours the development of well-adapted, mature, stable and integrated students, and an unfavourable family climate promotes non-adaptation, immaturity, lack of balance and insecurity.

The influence of family educational climate is defined by the amount and the style of help that children receive from the family; that is determined by elements of the family context, like the dynamic of communication and affective relationships, attitudes toward values, expectations et cetera (Diaz, 2004). Along these same lines, Marchesi and Martin (2002) reported that parental expectations have a notable influence on academic results, even when controlling for initial knowledge and socio-economic context. Castejon and Perez (1998) found indirect relationships with performance from the student's perception of how much importance his or her parents assign to study at home.

\section{Methodology}

The research designs used for this study were ex-post facto and correlation survey; because the study involves seeking opinion of students in their natural setting and correlating the findings. The area of study is Adamawa State. It is located within the North East Zone of Nigeria. According to Adebayo and Tukur (1999) Adamawa State lays between latitude $7^{\circ}$ and $11^{\circ}$ North of the equator and longitude $11^{\circ}$ and $14^{\circ}$ East of the 
Greenwich Meridian; with altitude of 185 meters above sea level. Adamawa State has twenty-one Local Government Areas, with land mass of $8,068 \mathrm{Km}^{2}$ (National Population Commission, 2006) and the State consist of five educational zones, namely, Ganye, Gombi, Mubi, Numan, and Yola respectively. All the secondary schools in the State are grouped under the five educational zones. There are many primary, secondary and tertiary schools in Adamawa State but this study is concerned only with the State Government owned senior secondary schools students.

The population of the study consisted of 8,548 senior secondary school students in class 2 in 2012/13 to 2013/14 academic sessions (Adamawa State Post Primary Schools Management Board (ADSPPSMB), (2013). A total sample of 900 students in senior secondary school class 2 (SSSC2) was drawn from the population using multi-stage random sampling technique to select 6 schools in each of the five educational zones; 15 students each from monogamous and polygamous family backgrounds in each selected school, giving 30 students per school. Thus, the sample technique selected 450 students each from monogamous and polygamous family backgrounds to constitute the 900 respondents in this study. This agrees with Toluhi (2001) who recommended a sample range of $10-30$ per cent of a population.

The instrument used to collect data for this study was a researcher designed questionnaire titled Home Environmental Factors and Students' Academic Achievement Test in Agricultural Science (HEFSAATAS) consisting of two sections A and B. Section A consisted of 15 home environmental factors items while section B was made up of 25 items for Students' Academic Achievement Test in Agricultural Science. The 40 questionnaire items covered all the objectives of the study and it required the respondents to indicate their opinion on level of influence of each factor on their academic performance. The instrument used a four-point scale, thereby, eliminating the option of no opinion $(4=$ very high influence; $3=$ moderate influence; $2=$ low influence; and $1=$ no influence). The instrument was validated (content and face validities) by three experts in the field of Agricultural Education, and it was field tested in a neighbouring State - Gombe, using 40 senior secondary School students in class 2; the instrument gave a reliability co-efficient of 0.78 using Cronbach Alfa. Inferential statistics z-test analysis and correlation were used to describe, analyse and interpret the data.

\section{Results}

Hypothesis One: Parental marital status will not have significant influence on students' academic performance in Agricultural Science at the secondary school

The data that answered this hypothesis are presented on Table 1

Table 1: The correlation z-test analysis on influence of parental marital status on students' academic performance in Agricultural Science

\begin{tabular}{lrrrrrrrr}
\hline Status & $\mathrm{N}$ & $\bar{X}$ & $\mathrm{SD}$ & df & $\mathrm{r}$ & $\mathrm{z}$-cal & Remarks \\
\hline Married & 480 & & & & & & & \\
Single & 150 & & & & & & & \\
Broken & 180 & & & & & & & \\
Divorced & 80 & & & & & & & \\
Widow & 10 & & & & & & \\
Parental marital status & 900 & 14.3 & 3.56 & & & & \\
& & & & 898 & 0.79 & 41.8 & Very high correlation \\
Academic achievement & 900 & 25.1 & 1.76 & & & & & \\
\hline
\end{tabular}

Significant at 0.05 level, degree of freedom $(\mathrm{df})=898, \mathrm{z}$-critical $=1.96$

Hypothesis Two: Family type (monogamy or polygamy) of parents will not have significant influence on students' academic performance in Agricultural

Science at the secondary school

The data that answered this hypothesis are presented on Table 2

Table 2: z-test analysis on influence of Family type on students' academic performance in Agricultural Science

\begin{tabular}{cccccccc}
\hline Family type & $\mathrm{N}$ & $\bar{X}$ & $\mathrm{SD}$ & $\mathrm{df}$ & $\mathrm{z}$-cal & $\mathrm{P}$ & Remarks \\
\hline Monogamy & 450 & 32.46 & 5.62 & & \multirow{2}{*}{8.48} & .000 & Significant $(\mathrm{P}<0.005)$ \\
Polygamy & 450 & 35.11 & 6.31 & & & & \\
\hline
\end{tabular}

Hypothesis Three: Family size in home of students will not have significant influence on academic performance of students in Agricultural Science 
The data that answered this hypothesis are presented on Table 3

Table 3: The correlation z-test analysis on influence of Family size in student's home on students' academic performance in Agricultural Science

\begin{tabular}{lcccccccc}
\hline Siblings & $\mathrm{N}$ & $\bar{X}$ & $\mathrm{SD}$ & df & $\mathrm{r}$ & $\mathrm{z}$-cal & Remarks \\
\hline$\leq 4$ & 290 & & & & & & & \\
$5-9$ & 460 & & & & & & & \\
$\geq 10$ & 150 & & & & & & & \\
Family size & 900 & 15.6 & 4.13 & & & & \\
& & & & 898 & 0.81 & 46.3 & Very high correlation \\
Academic achievement & 900 & 25.1 & 1.76 & & & & \\
\hline
\end{tabular}

\section{Discussion}

The first finding that parental marital status has a very high correlation with $r=0.79$, and have significant influence $(\mathrm{z}$ calculated $=41.8$ critical $=1.96$ ) on students' academic performance in Agricultural Science is supported by Ekanem (2004) who reported that harmonious home environment create emotional stability in the child at home and subsequently throughout his school life. Rodriguez (1986) also reported that a positive family climate favours the development of well-adapted, mature, stable and integrated students, and an unfavourable family climate promotes non-adaptation, immaturity, lack of balance and insecurity. The home environment that is tensed due to divorce or unhealthy atmosphere of quarrelling; fighting due to polygamy and large family size do not favour learning, as the mind of the pupils will not be settled in order to give room for creativity.

The second finding showed that family type has significant influence $(\mathrm{z}$ calculated $=3.48$ critical $=$ $\mathrm{P}<0.005$ ) on students' academic performance in Agricultural Science among the respondents in this study. This implies that children from nuclear families are likely to get better attention in terms of prompt provision of school materials such as books and other learning materials than those from polygamous homes where large family sizes are common. Therefore, the monogamous family favours learning by creating a more conducive learning environment, conflicts are easier to solve in the monogamous families than in the polygamous family; students from polygamous families are more likely to experience more psychological disturbances and problems than their counterparts from the monogamous families. This invariably affects student's performances in the school. The parenting style (democratic, authoritarian, etc) is also influential both in the students' educational process as well as in family-school relations.

The third finding that family size in homes of students has a very high correlation with $\mathrm{r}=0.81$ and have significant influence $(\mathrm{z}$ calculated $=46.3$ critical $=1.96)$ on academic performance of students in Agricultural Science at the senior secondary school in Adamawa State. In terms of the influence of family size in home emphasis was laid on the ability of the parents to provide necessary facilities or materials that can help in making the learning of school subjects easy for the pupils. This involves the provision of mini library for children which include textbooks for English, Mathematics, and Agricultural Science and for all the other school subjects, story books, and picture books and spelling charts, which will help the pupils to learn words identification, correct spellings, correct sentences, master the use of correct tenses in line with pictures et cetera. Hence, Ogbemudia and Aiasa (2013) maintained that physical and psychological conditions of the home environment affect the children academically.

\section{Conclusion}

Based on the findings from this study, it was concluded that parental marital status, family type and size have significant influences on the academic performances of students; and marital status of parents and their family sizes in particular have very high correlation with students' school achievement. So, parents and all significant others should provide a healthy, peaceful and conducive home environment for the educational growth, development and progress of their wards in school, at home and in life generally.

\section{Recommendations}

Based on the findings from this study, it was recommended that

1. Parents should maintain intact marriage and family institutions for good parenting and to serve as models for younger generations especially, their wards.

2. Parents should keep family types and sizes they can effectively sponsor, run and maintain bearing in mind the costs of good living for themselves and their children.

3. From this study, I discover the need to study influence of single parenthood (due to broken home, death, or widowhood) on academic performance of students in Agricultural Science. 


\section{References}

[1]. Adamawa State Post Primary Schools Management Board (ADSPPSMB) (2013). Statistics Unit

[2]. Adebayo, A. A. and Tukur, A. L. (1999). Adamawa State in maps. $1^{\text {st }}$ edition. Yola: Paraclete

[3]. Achieng, B. O. (2012). Influence of institutional capacity on academic performance of students in public secondary schools in Usigu Division - Bondo District Kenya. A Masters Thesis, University of Nairobi'

[4]. Adell, M. A. (2002). Estrategias para mejorar el rendimiento academicos des los adolescents. (Strategies for improving academic performance in adolescents). Madrid: Piramide

[5]. Adebule, S. O. (2004). Gender differences on a locally standardized anxiety rating scale in Mathematics for Nigerian secondary schools. Nigerian Journal of Counselling and Applied Psychology, 1, 22 -29

[6]. Adesehinwa, O. A. (2013). Effects of family type (monogamy or polygamy) on students' academic achievement in Nigeria. International Journal of Psychology and Counselling, 5 (7), 153 - 156 DOI 10.5897/IJPC10.012 ISBN 2141 - 2499

[7]. Adesehinwa O. A. and Aremu, A. O. (2010). The relationship among predictors of child, family, school, society and the government and academic achievement of senior secondary school students in Ibadan, Nigeria. Procedia Soc. Behav. Sci. 5, $842-$ 849 .

[8]. Bouote, C. A. (2001). Relations of autonomy and relatedness to school functioning and psychological adjustment during adolescence. Dissertation Abstracts International Section A: Humanities and Social Sciences, 62 (1).

[9]. Campbell, S. M. and Martin, R. A. (2003). Agricultural Education. Encyclopedia of Education. Encyclopedia.com 8 Jun. 2011 http://www.encyclopedia.com

[10]. Castejon, J.L. and Perez, A.M. (1998). Un mudelo casual-explicato de las variables psicosociales en el rendimiento academic. (A causal-explicative model of psycho-social variables in academic performance). Revista Bordon, 50 (2), $171-185$.

[11]. Collins, A. I. (2007). Social Studies for Schools. Ibadan, University Press Ltd.

[12]. Diaz, A. L. (2004). Personal, family, and academic factors affecting low achievement in secondary school. Electronic Journal of Research in Educational Psychology and Psychopedagogy, 1 (1), 43 - 66. ISBN 1696-2095

[13]. Egunsola, A.O.E. (2012). Assessment of factors influencing students' choice of Agricultural Science in senior secondary Schools in Gombe State, Nigeria. Ahmadu Bello University Journal of Vocational Studies; Vol. 6(1); 59 - 65.

[14]. Ekanem, T. F. (2004). The school as a substitute home in Q. I. Obinaju (Ed), Theory and Practice in Early childhood Education. Calabar; Nigeria, BON Ltd.

[15]. Emeke, E. A. (1984).relationship between personal problems and study habits. J. Appl. Psycho., 3, 113 - 129.

[16]. Epp, S. S. (2004). Discreet Mathematics with Applications. 3rd ed. New York: Brooks/Cole-Thomson.

[17]. Federal Government of Nigeria (1976). National policy on education. Lagos: NERDC

[18]. Freedman, D, (1999). From association of causation: some remarks on the history of statistics. Statistical Science, 14, $243-258$.

[19]. Marchesi, A. and Martin, E. (eds). (2002). Evaluacton de la educacion secundaria, Fotografia de una etapa polemica. (Evaluation in secondary education, Snapshot from a controversial era) Instituto IDEA, Madrid: SM

[20]. Myers, B. E., Brejah, L. M. and Dyer, J. E (2004). Solutions to recruitment issues of High School Agricultural Education programs. Journal of Agricultural Education, 45 (4): $12-21$.

[21]. National Population Commission (2006). Nigeria's National Census, Abuja: NPC Press.

[22]. Ogbemudia, M. I. and Aiasa, M. V. (2013). Influence of home environment on the academic performance of primary five pupils' in English Language in Orhionmwon Local Government Area of Edo State. Merit Research Journal of Education and Review, 1 (5), $120-125$.

[23]. Rodriguez, E. (1986). Vida familiar y fracas escolar: comparacion de grupos extremos de rendimiento. (Family life and school failure: a comparison of extreme performance groups). Tesina, Universidad Pontificia de Salamanca Toluhi, J. O. (2001). Fundamental of research methodology. Ilorin: Nigeria, Victory Publ. 